\title{
On Being an Infidel
}

\section{Simon Blackburn ${ }^{1}$}

Accepted: 12 March 2021 / Published online: 6 July 2021

(c) The Author(s) 2021

\section{Abstract}

The paper describes the difference between being an infidel and being either an atheist or an agnostic.

Keywords Infidel - Atheism - Agnosticism - Religion · Expressive views of religion · Lokayata $\cdot$ Apophatic traditions $\cdot$ Ritual $\cdot$ Durkheim

Infidelity in this context is a lack of faith in something (not, as in other contexts, a breach of trust). There are various things in which one may lack faith. I lack faith in homoeopathy, the pantheon of Greek or Norse Gods, my cat's ability to read my mind, and so on, as do all sensible people. But in the context of this collection, we are talking about lack of faith in some established religious doctrine, and in addition, I shall suggest, lack of faith in the virtues of established religious practices.

In the usage which I prefer, being an infidel is different from being an atheist. According to infidels, atheists share too much with theists, and so do people who sit on the fence, calling themselves agnostics. All three of those take seriously one key question: Does God exist? The theist answers in the affirmative. The atheist denies it. And the agnostic admits to not knowing the answer. However, the three of them share a presupposition: That we have here a definite question. For this to be so we must have some conception of what is being talked about. But infidels deny that we have any such conception. We think that when people try to put into words what they have in mind, they end up in contradiction or mystery, and where there is nothing but contradiction and mystery, there is nothing to give content to the question of existence.

As the late Richard Rorty would have put it, we infidels do not say God exists, or might exist, or does not or might not. We just say that 'God' is not one of our words. It marks out no path that we wish to tread.

Simon Blackburn

swb24@cam.ac.uk

1 University of Cambridge Trinity College, Cambridge, UK 
There are actually traditions in some major religions, including Hinduism and Christianity, which appear to accept this critique, or even to celebrate it. The great economist Amartya Sen recalls being nervous on wanting to confess his loss of faith to his grandfather, a pious Hindu. He was pleasantly surprised when the old man beamed and said that that was very good-it meant that he had joined the Lokayata tradition of Hinduism. And Christianity also has a tradition of 'negative theology', sometimes called the apophatic tradition, according to which nothing whatsoever can be said about God and his (or her, or their) properties. We poor finite humans cannot put words to it. It might even be blasphemy to suppose we can. It would be imagining God to be in some way something like ourselves as if, as Voltaire put it: 'God created man in his own image, and man returned the compliment'.

It is pleasant to find so much agreement. But the Lokayata tradition was also associated with Charvaka, a 'sceptical' or 'materialist' philosophy. An infidel may or may not like that association. It is one thing to say that religious terminology is imprecise and incapable of being given serious use, and a different thing to tie oneself to a general scepticism, or any general metaphysic such as the term materialism suggests. The doubt whether anything worth calling religious belief can be salvaged once it is admitted that nothing whatsoever can be said about the nature of the deity is more local and more precisely aimed than these general positions.

There is an important logical tradition that protects infidels. This says that any proposition affirming existence has to supply a predicate, a determination of what kind of thing is being said to exist. Affirming the existence of a deity about which nothing can be said transgresses against this principle. It is a fake existential claim, for, as Wittgenstein put it, 'nothing will do as well as something about which nothing can be said'. It is as if someone approaches us and asks whether a jubjub exists. We have to ask what is meant by the term, and if there is no definite answer, there is no definite question to discuss. If all we are told is that the jubjub is everywhere and nowhere, out of time but changeable, a bit like a human being yet a lot unlike a human being, then we would be wasting our time pursuing the question of its existence. We have been given nothing to get hold of. We cannot mount a search for it since nothing could be a signal of success or failure, any more than the hunting of the Snark, in Lewis Carroll's famous poem, was a real hunt.

If it were just scepticism or materialism that attacks the possibility of cognition of God, it might be dismissed as itself just a piece of ideology. This is why it is important to sidestep any such sweeping and wide-ranging claims. The more focussed reason for infidelity is the difficulty internal to many religions, of making any real sense of the being supposedly talked about in religious discourse. The masterpiece of this approach is David Hume's Dialogues concerning Natural Religion (Hume, 1824). Here there is one religious sceptic, Philo, who represents Hume's own voice. However there are two religious apologists. One, called Cleanthes, represents God as the divine architect, and argues that just as we can rationally interpret an artefact, such as a cathedral or a windmill or a watch, as the upshot of human design, so we can interpret the entire cosmos as an artefact of divine design. The other, Demea, has a rather different, more abstract conception of the deity. His God is beyond space and time, beyond change and contingency, independent and untouchable, in theological terminology a 'necessary existence' on which all contingent beings depend. 
One might think that it is easy to fuse these two conceptions of the deity, having the best of both worlds, as it were. But as the detail unfolds, it becomes apparent that there is no such reconciliation or fusion to be had. Indeed, long before the Dialogues finish, these two apparent allies are vigorously contemptuous of each other's position. Taking Cleanthes's comparison of the deity to a human architect or designer first, what does this give us? We can only get a sense of what an architect likes doing by seeing his or her own productions-the buildings they have produced. In the case of the world, we have the one creation to go on. This is the world we have to cope with, and about which we know a great deal. But it affords no sign that the architect has also created very different worlds, such as heaven or hell might be. As far as we can tell, the architect is happy with very grey worlds in which there is a mixture of happiness and misery, in which good deeds are not always rewarded, and in which peace is fragile, disease is rife, bad people often rise to the top, and death awaits every living thing. There is no sign that the architect ever intended anything different.

If we pursue the analogy with human design, we run into other problems. Really good human designs are not the product of one mind. They are evolutions in which hundreds of people have cooperated. Materials had to be invented, engineering problems solved, more primitive designs improved upon, and mistakes rectified, all by a long evolutionary process of trial-and-error. Are we to think that the same is true of the cosmos? It might be that our world is.

'very faulty and imperfect, compared to a superior standard; and was only the first rude essay of some infant deity, who afterwards abandoned it, ashamed of his lame performance: it is the work only of some dependent, inferior deity; and is the object of derision to his superiors: it is the production of old age and dotage in some superannuated deity; and ever since his death, has run on at adventures, from the first impulse and active force, which it received from him'. (Hume, 1824: 46)

In the Dialogues, the other theist, Demea, urges these objections to the anthropocentric analogy or model of the deity as an architect. But when it comes to Demea's own conception of the deity, the 'necessary existence' it turns out that we have no conception of a property or power that could give rise to such a thing. Since that is so, we might even suppose that this power, whatever it might be, belongs to the cosmos as a whole, so that although it evolves through countless endless changes, it 'must' go on existing. In that case, there is no need for a higher-order, theological layer of being-no need for a God. If we hanker after something necessary underlying the contingencies of the world, the continued existence of the cosmos we know and which we inhabit will do as well as anything else, anything 'outside' space and time.

Hume was not alone in doubting the possibility of anything worth calling religious thought. Thomas Hobbes (1588-1679) thought that manifestations of piety, such as prayer, or hymns of adoration were in order, but nevertheless made a nice comparison: 
But they that venture to reason of his Nature, from these Attributes of Honour, losing their understanding in the very first attempt, fall from one Inconvenience into another, without end, and without number; in the same manner, as when a man ignorant of the Ceremonies of Court, coming into the presence of a greater Person than he is used to speak to, and stumbling at his entrance, to save himself from falling, lets slip his Cloak; to recover his Cloak, lets fall his Hat; and with one disorder after another, discovers his astonishment and rusticity. (Hobbes, 1839: 677-678)

Hobbes seems not to have taken seriously the thought that if you have no idea what you are talking about, attitudes such as 'adoration' or 'worship' also fly out of the window. Hume was made of firmer stuff.

So much for theology. But I have sympathy with the view that it is mistaken, or perhaps it would be better to say, unimaginative or off-key, to think of religious frames of mind primarily in terms of belief. And it would be similarly misdirected to think that the belief component primarily concerns the existence of anything. I read both these insights into Hume's celebrated works on the philosophy of religion, but their lesson seems never to have been properly absorbed. Even Wittgenstein, I think, although he came close and certainly flirted with more adequate views, failed to take their measure properly, although I will be unable to substantiate that opinion here.

To make both my claims plausible, we can contrast a religious frame of mind with a simple case of mistaken ontology. Bertrand Russell's comparison with the empirically absurd belief that there exists a teapot flying in its own extraterrestrial orbit around the sun is a convenient example. The first obvious point is that nobody would think of belief in such a thing as itself religious. It has none of the hallmarks. It has nothing to do with the conduct of life, with ethics, with the formation of congregations, with ritual, with the sense of anything as sacred, and with consolation, hope, despair, or the many other emotional and social clothings of religion. It is simply a daft secular belief.

But now suppose some of those clothings arrive. The teapot is important to people. The texts describing it are sacred. Out of its spout issue instructions for living. There are proper ways to show respect for it, cemented into services and rituals. There are sacred sites, and taboos associated with it, and priests who interpret its sayings, or who alone are authorized to lift its hidden lid. It is forbidden, perhaps a capital offence, to mock it, or them. Many people assert that without the belief in the teapot, their lives would be meaningless. And so on and so on. The teapot has now become an object of veneration-a religious object.

Now my two claims can come further into focus. The first is that the religious clothing that arrived was not primarily a matter of belief. It was a matter of practical dispositions or stances towards things. It was partly like having a favourite poem in your head, or a preference for one kind of music or another. It was partly as well a commitment to some practices and some permissions and prohibitions: an immersion in a 'way of life'.

The second implication is that ontology has actually dropped out of the picture. It simply does not matter anymore whether there is such a teapot or not. A mythical teapot can perform the religious function of being a focus for emotions, attitudes, 
and social practices just as well as an actual teapot-better, in fact, since mythical teapots are not the objects of science. It will be no part of any religious practice to ask whether the teapot is pink or blue, how much it weighs, how wide it is, any more than we ask the same kinds of question about Odysseus or Krishna (Wittgenstein remarked that people who talk of God's all-seeing eye do not talk about his eyebrows). Teapot theologians would, rightly, be horrified at the idea of sending a spaceship to intercept the teapot: It is no part of the way of life that empirical confirmation or disconfirmation of that kind is to be had, nor that it would be remotely appropriate.

Hume said that religionists are in a 'somewhat unaccountable' state of mind, somewhere between belief and disbelief. We can now see what he may have meant. The story about the teapot has become serious - as serious as birth, death, marriage, or any of the other aspects of living that the texts and rituals and ordained forms regulate and symbolize. It will not do to mock these things. On the other hand, it is empirically disengaged, or if we like, empirically frivolous, for nothing empirical is relevant to its function as an intentional object, a focus for all the emotions and practices which the religious service of the teapot entails. Just as a child can be afraid of the Jabberwocky in Alice in Wonderland, without really having any conception of it ('it seems to fill my head with ideas', said Alice, 'but I do not know what they are'), so the religionist can pursue the object of veneration without any conception of it beyond a vague and changing kaleidoscope of imaginings.

I shall return to this interpretation of religious practices later. Meanwhile, we should note that by failing to share those imaginings, we infidels are free from bondage to the sacred texts that embody them. This does not mean that we mock those who put them in their lives, any more than we mock a particular taste in music or art. It just means that they are not ours. We do not go around, as some militant atheists have done, saying that religionists are deceived or stupid, although no doubt some are. But when they are, it is because of particular further aberrations. It is not stupid to like the music of, say, Elvis Presley, but it would be stupid to suppose that he is still alive, or to follow his teachings, if he had any, on climate science or the cure for a pandemic. It is not stupid to go to church on Sundays, but it would be stupid to accept the Biblical chronology according to which the earth is roughly 6000 years old.

Lack of faith is not just another kind of faith, although, again, it can go with particular secular faiths, and some of those might be equally subject to criticism. In the European Enlightenment, it went along with an optimistic faith in the power of reason to change things for the better. To some extent that faith has been justified: Science unlocked the industrial revolution, and more people today are far richer, and have far more opportunities and far better educations because of it. Nobody in their right mind would want to revert to pre-industrial medicine, or a world in which all the work has to be performed by human or animal muscle. But of course all too often visions of improvement have failed to materialize: Human moralities and politics show few signs of progress, and all too often the circles of light that we enjoy are surrounded by an enveloping and sometimes threatening gloom.

But infidels about established religions need not have particular views about progress. We may be as pessimistic as anyone can be about the permanence of a better 
world-indeed, given what the science of cosmology tells us, our own world of a stable solar system is not going to be permanent as in about five or so billion years the sun will run out of nuclear fuel, become a red giant, engulf the nearest planets, and kill all life on earth, before ending up as a smaller, but intensely dense red dwarf. People can take various attitudes to this, from discounting it as entirely insignificant to any of our own lives (my own attitude), to finding it intensely tragic and depressing. Wherever we stand on this, there is still plenty for us, living here and now, to get right or wrong as we try to steer towards a better future.

Suppose we accept Hobbes's and Hume's critique of attempts to say what the deity is, but also take note of the non-cognitive, emotional nature of religious practice. Does this give that practice a kind of blank cheque, no more subject to scepticism than music or dancing? I do not think so. For whatever Hobbes may have thought, the confidence that their deities are describable is far more central to most religionists' conception of things, than this implies. Gods are described as having issued commandments, as having spoken directly to particular prophets and favourite peoples. They are described as having desired sacrifices or directed events. In many believers' minds, it is because they have manifested themselves that particular prescriptions that they are supposed to have communicated have their force and command our allegiance. And infidels do need to be sceptical about these beliefs and the associated attitudes. There is much we need to debate about politics and morality, but supposing that one side or another has the stamp of divine approval cannot change the debate one jot. You cannot put God's will into the scales on one side or the other, for we cannot measure the weight of Gods who cannot be comprehended. Perhaps after all, they just do not care.

I said at the beginning that it was possible to be an infidel not only when it comes to religious doctrine, but also when it comes to religious practice, but this needs heavy qualification. I do not, of course, deny that many people sincerely perform religious rites, sing religious songs and chants, and have their heads full of religious words. These things happen. Nor do I deny that people find that these rites, songs, and words give them consolation and hope, and change their orientations to the world in important ways. If a child is taught to take consolation in the fact that Jesus is looking after our paths in life, it has an effect, for as the philosopher the late Roger Scruton put it, the consolation of an imaginary friend is not an imaginary consolation. The hope that Santa Claus will visit tonight is a real enough hope, and the excitement it generates a real enough excitement. Most, but not all, philosophers of the emotions agree that at the cinema, our fear that the villain will harm the heroine is real fear, even when at the same time we know that both are fictions.

I think it is very difficult to draw up a cost-benefit account of the value of these mental states. Living in a fool's paradise can be more pleasant than living in the real world. William James even thought that this was a sufficient defence of religious belief itself, not on the grounds of its truth, but on the grounds of its pleasant effects. 
It is only when we take into account the larger-scale effects, either in the religionist's own life or in the society in which the habit of succumbing to illusions are embedded that the dark side really emerges. The habit of succumbing to wishful thinking and illusion, as W. K. Clifford famously saw when he wrote his brilliant riposte to James, has us ignoring a duty to reason:

He who truly believes that which prompts him to an action has looked upon the action to lust after it; he has committed it already in his heart. If a belief is not realized immediately in open deeds, it is stored up for the guidance of the future. It goes to make a part of that aggregate of beliefs which is the link between sensation and action at every moment of all our lives, and which is so organized and compacted together that no part of it can be isolated from the rest, but every new addition modifies the structure of the whole. No real belief, however trifling and fragmentary it may seem, is ever truly insignificant; it prepares us to receive more of its like, confirms those which resembled it before, and weakens others; and so gradually it lays a stealthy train in our inmost thoughts, which may someday explode into overt action. (Clifford, 1879:181)

Clifford talks here of beliefs, and even if we try to sideline the place of belief in religious practice, the practices have similar expressions in behaviour. The rites and songs and words enter our hearts, colouring some doings with emotions, not only consolation, fear, and hope, but also emotions of identity and self-righteousness. Religionists think that without the religious atmosphere in which they clothe their world, things would be different, and very likely much worse, as if meaning would have been drained out of the universe.

What believers take to be the independent wishes of the gods are in fact bubbles in their own brains, installed by tradition, magnified by repetition, and then projected upon the universe, as if it is its very own voice that is speaking. Such fantasies and fixed ideas may be harmless. They may not harm those who indulge them, and may even be beneficial to them insofar as they bring about positive attitudes, such as hope or consolation. But at least as often, they are invitations to mistrust or hatred of those who do not share the particular bubble that the person of faith inhabits.

One of the moral peculiarities of the contemporary world is the hair-trigger propensity to take offence. When people meet others who do not share their views, they are quick to form suspicions and resentments. They put on the cloak of victimhood, and accuse those who fail to agree with them of disrespect and offensiveness. It is as if by failing to fall into their bubble we, the outsiders, are automatically diminishing them, perhaps even denying their humanity and their rights. It is possible to think that distinguishing infidelity from atheism can also do something to assist this process. For atheists, as we have seen, deny something that the faithful assert. But infidels do not. Their attitude is more like one of hearing a foreign language, sayings using words that are not their own, and of which they can make almost nothing. It need be no sign of disrespect to feel like this.

But I fear that this is only one side of the coin. When we do not join in a conversation in a foreign language, because their words are not our words, we do not thereby suppose that the others are failing to make sense. This lack of communication is our 
fault, rather than theirs. But when we hear theologians arguing over the nature of God and God's will, we do suppose that they are deceived. They think they have an intelligible topic, but they have none. And this implies an attitude which if not itself disrespectful, is certainly close to it. It is going to be like coming upon someone who spends energy on completely worthless pursuits, like counting the blades of grass in the lawn.

The great sociologist and anthropologist Emile Durkheim, who studied religions across the world, concluded that their real function was just this of not only binding people into cohesive units, cementing the authority and identity of the tribe, but also insisting on the difference from other tribes.

Being true to infidelity means being suspicious of all that, and perhaps being in despair at its prevalence in the contemporary world. The hair-trigger propensity to take offence makes it more dangerous now than it used to be, not only in theocratic countries like Iran or Bangladesh, but even in the once-liberal West. Difference is becoming identified with contempt, and contempt with hatred, which is in turn becoming illegal. It should be part of any good education to wean people away from these childish sentiments. An education in philosophy can certainly help that by teaching that there are two sides to many questions, that one's first thoughts may not be one's best, and that we live in the midst of uncertainty and debate. But until such an education takes root, infidels, like sceptics, will not be to everyone's taste.

Open Access This article is licensed under a Creative Commons Attribution 4.0 International License, which permits use, sharing, adaptation, distribution and reproduction in any medium or format, as long as you give appropriate credit to the original author(s) and the source, provide a link to the Creative Commons licence, and indicate if changes were made. The images or other third party material in this article are included in the article's Creative Commons licence, unless indicated otherwise in a credit line to the material. If material is not included in the article's Creative Commons licence and your intended use is not permitted by statutory regulation or exceeds the permitted use, you will need to obtain permission directly from the copyright holder. To view a copy of this licence, visit http://creativecommons.org/licen ses/by/4.0/.

\section{References}

Clifford, W. K (1879). Lectures and essays, Vol. 2. Eds. Leslie Stephen \& Fredrick Pollock. Macmillan and Co.

Hobbes, T (1839). The English works of Thomas Hobbes of Malmesbury, Vol. 3. Ed. William Molesworth. John Bohn.

Hume, D. (1824). Dialogues concerning natural religion, in The Philosophical Works of David Hume, G. Fenton.

Publisher's Note Springer Nature remains neutral with regard to jurisdictional claims in published maps and institutional affiliations. 